\title{
Winter crop choice and body condition loss change the ecoefficiency of sheep flocks
}

\author{
Anna TAYLOR ${ }^{1 *}$, David R. STEVENS ${ }^{2}$, and Sue A. MCCOARD ${ }^{3}$ \\ ${ }^{1}$ Lincoln Research Centre, AgResearch, Private Bag 4749, Christchurch. \\ ${ }^{2}$ Invermay Research Centre, AgResearch, Private Bag 50034 Mosgiel, New Zealand. \\ ${ }^{3}$ Grasslands Research Centre, AgResearch, Private Bag 11008, Palmerston North.
}

*Corresponding author: anna.taylor@agresearch.co.nz

\begin{abstract}
Research has highlighted reproduction losses when feeding low protein winter crops, such as fodder beet. The following study compared the impact of body condition score (BCS) change (0 or -0.5$)$ with a winter feed choice of brassicas (adequate protein) or fodder beet (low protein) on sheep production, greenhouse gas emissions and $\mathrm{N}$ and $\mathrm{P}$ losses in two environments in the South Island of New Zealand. Eight farms were chosen from an existing database, with high $(1090 \mathrm{~mm} / \mathrm{annum})$ or low $(590 \mathrm{~mm} /$ annum) rainfall. Farm estimates of BCS were modified to fit the change scenarios and ewe and lamb survival at lambing, and lamb liveweight gain to weaning were altered to reflect the impacts of BCS when fed either adequate or low protein diets in mid-tolate pregnancy. Meat and fibre production, greenhouse gas emissions and $\mathrm{N}$ and $\mathrm{P}$ losses were calculated for the four scenarios using Farmax and Overseer models. Loss of BCS in winter led to greater ecoefficiency per hectare as less lambs were produced. Feeding fodder beet without additional protein reduced overall production and ecoefficiency per unit of product to a greater extent than just lower BCS. N and P losses were low and were reduced when feeding fodder beet.
\end{abstract}

Keywords: Winter crops, feed supply, climatic variation, profit, farming enterprise.

\section{Introduction}

Winter crops are an integral part of many cool temperate sheep and beef farm systems in New Zealand. Often between 3 and $5 \%$ of the farm may be as a winter crop (Stevens et al., 2021). Fodder beet (Beta vulgaris) has become a greater part of the winter crop portfolio in recent times, with over 15,000 ha planted annually (Gibbs 2014). Fodder beet has high yields, averaging approximately 19 t DM/ha (Judson et al., 2016). Swedes (Brassica napus) are a winter crop with major storage of carbohydrates in the bulb, but its yields are lower than fodder beet, often being between 10-15 t DM/ha (Chakwizira et al., 2011; Gowers et al., 2006). However, recent advances in plant breeding have provided cultivar and management systems that can increase yield by up to $30 \%$, (Dumbleton et al., 2012), providing the potential for swedes to attain the yields of fodder beet.

Yields of high yielding root crops principally comprise approximately $80-85 \%$ bulb which has a high sugar content (Judson et al., 2016). This provides a high energy concentration, but is moderated by a low protein concentration, typically 7-9\% (Chakwizira et al., 2013). This protein concentration varies depending on cultivar, (Prendergast and Gibbs 2015), but is generally low and may not meet the demand of the animal in some physiological states (Pacheco et al., 2016).

High yielding forage is used to meet animal demands in winter, while minimising the area required to be sown with winter crops (Milne et al., 2014). However, new research has highlighted reproduction losses when feeding winter crops which are low in protein, such as fodder beet (Hammond et al., 2021). When fed fodder beet in mid to late pregnancy, twin-bearing ewes lost body condition (BCS) and showed signs of undernutrition due to protein deficiency. This led to lambs being born smaller and poorer lamb survival and growth to weaning than those from ewes fed pasture diets. Supplementing a fodder beet diet to provide adequate protein has been shown to prevent the loss in BCS and the reduction in lamb birth weight (Knol et al., 2019).

The BCS loss in late pregnancy has been linked to reductions in lamb survival (Everett-Hincks et al. 2004; McCoard et al., 2020) and liveweight gain from birth to weaning (Corner-Thomas et al., 2015) and has been related to ewe death rate in commercial flocks (MorganDavies et al., 2008; Flay et al., 2021). Lamb survival and growth (i.e., ewe reproductive performance) are key levers to changing eco-efficiency, particularly in hill country systems (MacKay et al., 2012). Of specific interest are changes in greenhouse emissions and nitrogen and phosphorus losses into water courses.

The following trial tested the hypothesis that winter crop choice, specifically low protein fodder beet, is involved with a mid-to-late pregnancy loss of BCS to reduce whole farm eco-efficiency, represented as greenhouse gas (GHG) emissions and nitrogen $(\mathrm{N})$ and phosphorus (P) losses from soil. To test the robustness of this hypothesis, two farm classes, South Island hill country and South Island breeding/finishing, were used, representing high and low rainfall zones. 


\section{Materials and Methods}

The impact of feeding winter crops on the reproductive performance of a ewe flock and its subsequent effects on the eco-efficiency of mixed livestock farms was investigated. The experimental design was a two-bytwo factorial with four replicates and farm environment as a blocking factor. The two factors were BCS change in mid-to-late pregnancy (0 or - 0.5$)$ and adequate or low protein diets (Control or Fodder beet). BCS was determined using the industry 1-5 scale (Jefferies 1961).

\section{Farm selection and base modelling}

Eight farms (replicates) were anonymously selected from an existing database to represent two environments, 'high rainfall' (four farms, $1090 \mathrm{~mm} /$ annum) representing Class 6 Beef + Lamb NZ (2021a)
South Island Finishing Breeding farms, and 'low rainfall' (four farms, $590 \mathrm{~mm} / \mathrm{annum}$ ) representing Class 2 Beef + Lamb NZ (2021b) South Island Hill Country with a cool temperate climate in southern New Zealand (Table 1). Criteria for selection included no dairy support, a representative balance of steep, rolling and flat land, winter crop use and farm size (Beef + Lamb NZ 2021). Current production metrics were used as the base condition for each farm (Table 1 and 2) and converted into a model farm using the Farmax (Marshall et al., 1991) Red Meat (version 8.0.1.34 Science Edition) whole farm modelling software and OverseerSci (version 3.4.1.0) (Shepherd and Wheeler 2012) nutrient budgeting tool. These tools were used in subsequent modelling for production, GHG and $\mathrm{N}$ and $\mathrm{P}$ losses.

Table 1 Physical parameters of four high rainfall (B+LNZ farm class 6 South Island Finishing breeding) and four low rainfall (B+LNZ farm class 2 South Island Hill Country) farms chosen to test the impacts of BCS change and winter forage choice on production, greenhouse gas emissions and $\mathrm{N}$ and $\mathrm{P}$ loss.

\begin{tabular}{|c|c|c|c|c|c|c|c|c|c|}
\hline \multirow[b]{2}{*}{ Farm ID } & \multirow[t]{2}{*}{$\begin{array}{l}\text { Rainfall } \\
\text { (mm/yr) }\end{array}$} & \multicolumn{2}{|c|}{$\begin{array}{c}\text { Farm } \\
\text { area (ha) }\end{array}$} & \multicolumn{3}{|c|}{$\begin{array}{l}\text { Topography } \\
\text { (ha) }\end{array}$} & \multicolumn{3}{|c|}{$\begin{array}{l}\text { Crop yield } \\
\text { (t DM/ha) }\end{array}$} \\
\hline & & Total & Effective & Flat & Rolling & Steep & $\begin{array}{l}\text { Winter } \\
\text { feed (ha) }\end{array}$ & $\begin{array}{c}\text { Swede/ }{ }^{1} \\
\text { Kale }\end{array}$ & $\begin{array}{l}\text { Fodder } \\
\text { Beet }^{1}\end{array}$ \\
\hline High rainfall 1 & 840 & 640 & 540 & 0 & 450 & 190 & 34 & 8.4 & 21.0 \\
\hline High rainfall 2 & 1170 & 834 & 734 & 36 & 637 & 161 & 71 & 11.7 & 29.3 \\
\hline High rainfall 3 & 1250 & 458 & 290 & 65 & 343 & 50 & 11 & 12.5 & 31.3 \\
\hline High rainfall 4 & 1110 & 422 & 410 & 0 & 324 & 98 & 19 & 11.1 & 27.8 \\
\hline Low rainfall 1 & 500 & 871 & 860 & 400 & 271 & 200 & 51 & 5.0 & 12.5 \\
\hline Low rainfall 2 & 585 & 340 & 337 & 0 & 340 & 0 & 30 & 5.9 & 14.6 \\
\hline Low rainfall 3 & 600 & 736 & 490 & 156 & 32 & 548 & 9 & 6.0 & 15.0 \\
\hline Low rainfall 4 & 675 & 805 & 790 & 0 & 360 & 445 & 38 & 6.8 & 16.9 \\
\hline
\end{tabular}

${ }^{1}$ Crop yields calculated from rainfall assuming $50 \%$ of the annual rainfall was utilised in growing the crop (De Ruiter et al., 2009; Chakwizara et al., 2014)

Table 2 Farm performance of four high rainfall (B+LNZ farm class 6 South Island Finishing breeding) and four low rainfall (B+LNZ farm class 2 South Island Hill Country) farms chosen to test the impacts of BCS change and winter forage choice on production, greenhouse gas emissions and $\mathrm{N}$ and $\mathrm{P}$ loss.

\begin{tabular}{lccccc}
\hline Farm ID & $\begin{array}{c}\text { Stocking Rate } \\
\text { (SU/Farm ha) }\end{array}$ & $\begin{array}{c}\text { Sheep:cattle ratio } \\
\text { (kg eaten/kg } \\
\text { product) }\end{array}$ & $\begin{array}{c}\text { Net pasture } \\
\text { production } \\
\text { (kg DM/haeff) }\end{array}$ & $\begin{array}{c}\text { Feed Conversion } \\
\text { efficiency }\end{array}$ & $\begin{array}{c}\text { Animal Product } \\
\text { (kg meat and } \\
\text { wool/haeff) }\end{array}$ \\
\hline High rainfall 1 & 7.3 & $78: 22$ & 3,831 & 25.0 & 134 \\
High rainfall 2 & 13.4 & $70: 30$ & 7,077 & 22.3 & 289 \\
High rainfall 3 & 13.6 & $91: 9$ & 7,259 & 22.5 & 208 \\
High rainfall 4 & 9.3 & $93: 7$ & 4,825 & 26.2 & 187 \\
Low rainfall 1 & 6.7 & $82: 18$ & 3,519 & 25.2 & 142 \\
Low rainfall 2 & 9.1 & $61: 39$ & 4,783 & 23.4 & 211 \\
Low rainfall 3 & 7.2 & $74: 26$ & 4,148 & 24.6 & 107 \\
Low rainfall 4 & 6.8 & $83: 17$ & 3,754 & 22.8 & 161 \\
\hline
\end{tabular}

eff Effective area of the farm. The BCS change for the chosen farms averaged -0.3 BCS from scanning to lambing. 
Impacts of body condition score on reproductive parameters

The BCS in mid-to-late pregnancy impacts on the reproductive performance of sheep, including ewe mortality (Morgan-Davies et al., 2008; Flay et al., 2021), lamb mortality ((Everett-Hincks et al., 2004; McCoard et al., 2020), and liveweight gain to weaning (Stevens et al., 2012; Mathias et al., 2013; Everett-Hincks et al., 2013). While these factors have been noted, actual whole flock response to BCS change has not been well documented. McCoard et al., 2020) noted that avoiding BCS loss may be more important than pre-winter BCS. For this reason, data from a commercial flock, over two seasons, using 2200 recorded ewes, was used to measure reproductive performance in relation to changes in BCS, rather than any static BCS parameter. A description of this flock has been published by Johns et al. (2016). Using the full data set, the following equations were created to represent ewe mortality and lamb mortality, in response to BCS changes during mid-to-late pregnancy.

Ewe mortality rate $(\%)==+3.49 * \Delta \mathrm{BCS}^{2}$ $4.12 * \Delta B C S+3.5\left(r^{2}=0.988\right)$

[Equation 1]

This provided comparable mortality rates to those previously published (Morgan-Davies et al., 2008; Flay et al., 2021).

Lamb loss $(\%)=7.76^{*} \Delta \mathrm{BCS}^{2}-3.79 \Delta \mathrm{BCS}+14.9\left(\mathrm{r}^{2}\right.$ $=0.943)$

[Equation 2]

This provided comparable lamb mortality rates to those previously published (Everett-Hincks et al., 2013; McCoard et al., 2020). Changes in lamb liveweight gain from birth to weaning were calculated from the literature (Stevens et al., 2012; Mathias et al., 2013; Everett-Hincks et al., 2013) and resulted in the following equation:
Lamb liveweight gain change $(\mathrm{g} / \mathrm{d}$, birth to weaning $)=$ $30 * \triangle \mathrm{BCS}$

[Equation 3]

Finally, a further adjustment was made to reflect feeding the low protein diet during mid-to-late pregnancy, based on the work of Hammond et al., (2021).

Equation 4: Lamb loss $(\%$, low protein diet $)=2 *$

[Equation 4]

\section{Adjustments to reproductive performance of the base models}

The reproductive performance on each farm was altered to reflect the impact of changing BCS in mid-tolate pregnancy using equations 1-4. Initially, ewe BCS changes from scanning to lambing within each base farm was calculated from true liveweight difference estimates from the Farmax files, using the relationship $1 \mathrm{BCS}=10 \%$ of true liveweight (Kenyon et al., 2014). To standardise the comparison between farms, live weight profiles and reproductive performance were adjusted relative to the calculated BCS changes on each farm (Table 3), using equations $1-4$ to fit the 0 or -0.5 BCS change criteria.

\section{Mid-to-late pregnancy feeding}

Control scenarios used either kale (Brassica oleracea) or swedes (Brassica napus) as the winter crop. The area of crop in the Control 0 and Control -0.5 scenarios was taken from the area on the base farms (Table 1). Winter crop yields were determined using calculations from published research, as these were not available for each farm. Yields of swedes or kale were calculated using the growth relationship of $20 \mathrm{~kg}$ DM per mm of rainfall (Table 1), assuming that half of the annual rainfall was available during the growing period (de Ruiter et al., 2009).

Table 3 Ewe reproductive parameters of four high rainfall (B+LNZ farm class 6 South Island Finishing breeding) and four low rainfall ( $B+L N Z$ farm class 2 South Island Hill Country) farms chosen to test the impacts of BCS change and winter forage choice on production, greenhouse gas emissions and $\mathrm{N}$ and $\mathrm{P}$ loss.

\begin{tabular}{lcccc}
\hline Farm ID & Scanning \% & $\begin{array}{c}\text { Ewe liveweight } \\
\text { at scanning (kg) }\end{array}$ & $\begin{array}{c}\text { BCS change from } \\
\text { scanning to lambing (kg) }\end{array}$ & $\begin{array}{c}\text { Lamb Weaning } \\
\text { weight (kg) }\end{array}$ \\
\hline High rainfall 1 & 155 & 63 & -0.29 & 28.2 \\
High rainfall 2 & 186 & 74 & -0.29 & 33.0 \\
High rainfall 3 & 197 & 76 & -0.32 & 31.6 \\
High rainfall 4 & 145 & 61 & -0.40 & 28.0 \\
Low rainfall 1 & 146 & 61 & -0.40 & 26.6 \\
Low rainfall 2 & 164 & 65 & -0.26 & 26.2 \\
Low rainfall 3 & 191 & 65 & -0.38 & 28.7 \\
Low rainfall 4 & 202 & 74 & -0.17 & 28.5 \\
\hline
\end{tabular}


In the fodder beet scenarios, enough was planted to replace other forage crops to meet the final 45 days feed requirements for breeding ewes before set stocking at approximately 3 weeks before lambing. This maintained a consistent DM available from the winter crops, as per the equation:

Fodder beet area $=$ total tonnes $\mathrm{DM} /$ fodder beet yield [Equation 5]

Fodder beet yields were calculated assuming growth rates of $50 \mathrm{~kg}$ DM per mm of rainfall and that half of the annual rainfall was available over the growing period (Chakwizara et al., 2014).

Supplementing a fodder beet diet with adequate protein has been shown to prevent BCS loss and return lamb birth weights to normal (Knol et al., 2019). Thus, in the BCS 0/Fodder beet scenario, a supplement $(0.5$ $\mathrm{kg} \mathrm{DM} / \mathrm{d}$ ) was included to provide adequate protein. The area of fodder beet grown on farm was further reduced to offset the amount of supplement fed. The fodder beet diet for no BCS change was 30\% lucerne hay/chaff, $13 \%$ soy meal, $1 \%$ urea, $56 \%$ fodder beet, to provide a low-cost feed, following Knol et al. (2020).

\section{Farmax modelling criteria}

General adjustments made to ensure pasture use was similar to the original farms included adjusting lamb sales date, supplement making, stocking rate and autumn nitrogen use (Table 4). As changing flock

Table 4 Decision rules used to ensure that feed supply and demand profiles of each scenario were reflective of the original base farms.

\begin{tabular}{lll}
\hline Description & Model condition & Management decisions \\
\hline $\begin{array}{l}\text { The model calculates that the pasture cover } \\
\text { and/or quality in spring is not sufficient to } \\
\text { feed animals on the farm }\end{array}$ & Spring feed deficit & $\begin{array}{l}\text { Add Nitrogen fertiliser at up to } 40 \mathrm{~kg} \mathrm{~N} / \mathrm{ha} \text { to rolling } \\
\text { land only }\end{array}$ \\
\hline
\end{tabular}

For a model to represent a long-term farm system the pasture covers need to balance at the 'start' (1 July) and 'end' (30 June). This is influenced by feed requirements of the animals on-farm and the pasture growth rates.
End cover too low (greater than $50 \mathrm{~kg} \mathrm{DM} / \mathrm{ha}$ different to opening cover)

For every $1 \mathrm{~kg}$ of DM deficient, shift the sale of 3 lambs from the end of year to one week after weaning

Move all lamb sales after end April to a week after weaning as store sales

If new sale after weaning carcass weight exceeds the actual weight of the next sale then make a prime, rather than a store sale

End cover too high (greater than $50 \mathrm{~kg} \mathrm{DM} / \mathrm{ha}$ different to opening cover)

Make baleage, on flat land if available. Close up paddock after 1st Jan for 62 days and adjust area until closing covers match

Remove any autumn nitrogen applications (not crop or DAP application)

Sell surplus baleage at a price of $\$ 80 / \mathrm{bale}$

Pasture cover surplus (more feed than required) reduces the quality of the pasture/feed

Altering the ewe reproductive parameters from the baseline, determined for each scenerio if there were more or less lambs than the base file that needed to be sold.
Summer surplus $(>2,800 \mathrm{~kg} \mathrm{DM} / \mathrm{ha})$

Make baleage with same rules as end cover too high

More lambs

Sold on the $16^{\text {th }}$ of each month (except in early sale in which date after weaning) proportionately to original file. No more than $10 \%$ of lamb sales after May.

Less lambs

Sale numbers reduced each month proportionately to original file, using the sale closest to the middle of the month if possible, otherwise the biggest sale number

Lamb deaths Increased/deceased proportionately to original file \%

Ewe deaths Increased number of ewe hoggets retained to balance ewe numbers 
performance and area cropped resulted in variations in whole-farm feed supply, alterations were made to ensure that pasture covers at the beginning (1 July) and end (30 June) of the modelling cycle were representative of mid-winter.

The GHG model within Farmax was used and was based on algorithms from the New Zealand national inventory (Ministry for Primary Industries 2021) and limited to methane and nitrous oxide emissions from excreta from all the animals (beef and sheep), but excluding slope-based nitrous oxide emissions factors, and any applied $\mathrm{N}$ fertiliser. Overseer Science (version (C) 2018 | 3.4.1.0) was used to examine farm environmental outcomes for losses of $\mathrm{N}$ and $\mathrm{P}$ losses from soil in each of the scenarios.

\section{Data analysis}

The effect of high or low rainfall was analysed using each farm as a replicate to provide a description of the two environments representing Class 2 and 6 farm types (Beef + Lamb NZ 2021). Variables included pasture and supplement (including crop) consumed, proportion of area cropped, sheep:beef ratios and stocking rate. Ecoefficiency factors analysed included sheep and beef production ( $\mathrm{kg}$ product/ha/annum), methane and nitrous oxide emissions $(\mathrm{kg} \mathrm{CO}$ E/ha/annum and $\mathrm{kg}$ $\mathrm{CO}_{2} \mathrm{E} / \mathrm{kg}$ product), total $\mathrm{GHG}$ emissions $\left(\mathrm{kg} \mathrm{CO} \mathrm{CO}_{2} \mathrm{E} /\right.$ ha/annum), emissions intensity ( $\mathrm{kg} \mathrm{CO}_{2} \mathrm{E} / \mathrm{kg}$ product) and nutrient loss ( $\mathrm{N}$ and $\mathrm{P} \mathrm{kg} / \mathrm{ha} /$ annum). Results of the two-by-two factorial with BCS change (0 or - 0.5$)$ and winter crop (brassica or fodder beet) as main factors were analysed using rainfall (high or low) as a blocking factor and individual farms as replicates. A number of covariates were explored, including stocking rate, initial productivity ( $\mathrm{kg}$ product/ha), farm size and beef enterprise (\% stock units as beef). Only the proportion of beef explained any further variation, and this was retained in all analyses. All analyses used the REML function of the statistical package Genstat (version 18, 2017).

\section{Results}

Comparing high and low rainfall environments

High or low rainfall resulted in significant differences between many of the factors analysed, including greater pasture production, more productivity, higher stocking rate and higher GHG emissions per hectare (3.0 vs. $2.2 \mathrm{t} / \mathrm{h}$ a respectively) in the high rainfall environments $((\mathrm{P}<0.01$; Table 5). Sheep production was greater in the high rainfall environment, while beef production

Table 5 Production parameters, greenhouse gas emissions and nutrient loss from sheep and beef farms in high or low rainfall environments, when modelled in cool, temperate southern New Zealand.

\begin{tabular}{|c|c|c|c|c|}
\hline Parameters & & High rainfall & Low rainfall & LSD \\
\hline Rainfall & (mm/annum) & 1090 & 590 & \\
\hline Topography & (Flat:Rolling:Steep) & $5: 75: 20$ & $17: 45: 38$ & \\
\hline Pasture consumed & $(\mathrm{t} / \mathrm{ha})$ & $5.25^{\text {a1 }}$ & $3.47^{b}$ & 0.38 \\
\hline Supplement consumed & $(\mathrm{t} / \mathrm{ha})$ & $0.75^{a}$ & $0.55^{b}$ & 0.09 \\
\hline Proportion of area cropped & & 6.1 & 5.4 & 2 \\
\hline Sheep: beef ratio & & $83: 17$ & $74: 26$ & \\
\hline Stocking rate & (SU/ha) & $10.9^{a}$ & $7.3^{b}$ & 0.8 \\
\hline \multirow[t]{5}{*}{ Sheep } & Product (kg/ha/yr) & $179.4^{\mathrm{a}}$ & $103.4^{b}$ & 24.3 \\
\hline & Methane (kg CO$\left.{ }_{2} \mathrm{E} / \mathrm{ha} / \mathrm{yr}\right)$ & $1950^{a}$ & $1296^{b}$ & 80 \\
\hline & Methane (kg CO${ }_{2} \mathrm{E} / \mathrm{kg}$ product) & $10.9^{b}$ & $12.5^{a}$ & 1.3 \\
\hline & $\mathrm{N}_{2} \mathrm{O}\left(\mathrm{kg} \mathrm{CO} \mathrm{CO}_{2} / \mathrm{ha} / \mathrm{yr}\right)$ & $443^{a}$ & $296^{b}$ & 19 \\
\hline & $\mathrm{N}_{2} \mathrm{O}$ (kg CO${ }_{2} \mathrm{E} / \mathrm{kg}$ product) & $2.47^{b}$ & $2.80^{a}$ & 0.28 \\
\hline \multirow[t]{5}{*}{ Beef } & Product (kg/ha/yr) & $32.9^{b}$ & $42.9^{a}$ & 4.3 \\
\hline & Methane $\left(\mathrm{kgCO}_{2} \mathrm{E} / \mathrm{ha} / \mathrm{yr}\right)$ & $470^{b}$ & $535^{a}$ & 29 \\
\hline & Methane $\left(\mathrm{kgCO}_{2} \mathrm{E} / \mathrm{kg}\right.$ product $)$ & $14.3^{a}$ & $12.5^{b}$ & 0.37 \\
\hline & $\mathrm{N}_{2} \mathrm{O}\left(\mathrm{kg} \mathrm{CO} \mathrm{CO}_{2} \mathrm{E} / \mathrm{ha} / \mathrm{yr}\right)$ & $100^{b}$ & $112^{a}$ & 7 \\
\hline & $\mathrm{N}_{2} \mathrm{O}$ (kg CO $\mathrm{CO}_{2} \mathrm{E} / \mathrm{kg}$ product) & $3.04^{a}$ & $2.61^{b}$ & 0.08 \\
\hline Total greenhouse gas emission ${ }^{\mathrm{s}} 1$ & (kg CO$\left.{ }_{2} \mathrm{E} / \mathrm{ha} / \mathrm{yr}\right)$ & $2998^{a}$ & $2259^{b}$ & 86 \\
\hline Emission intensity & (kg CO${ }_{2} \mathrm{E} / \mathrm{kg}$ product) & 14.85 & 15.51 & 1.88 \\
\hline \multirow[t]{2}{*}{ Nutrient loss } & $\mathrm{N}(\mathrm{kg} / \mathrm{ha} / \mathrm{yr})$ & $12.98^{a}$ & $9.69^{b}$ & 2.07 \\
\hline & $\mathrm{P}(\mathrm{kg} / \mathrm{ha} / \mathrm{yr})$ & $0.88^{a}$ & $0.10^{b}$ & 0.06 \\
\hline
\end{tabular}

${ }^{1}$ Means with differing superscripts within rows are significantly different $(P<0.05) ;{ }^{2}$ All farm emissions including fertiliser use 
was higher in the low rainfall environment (Table 5). Methane and nitrous oxide emissions from sheep meat production, while greater per hectare $(\mathrm{P}<0.01)$ in the high rainfall environment, were lower per $\mathrm{kg}$ of product $(\mathrm{P}<0.01)$ in the low rainfall environment. Beef enterprises in low rainfall environments produced more methane and nitrous oxide emissions per hectare than those in high rainfall environments $(\mathrm{P}<0.01)$ but lower emissions per $\mathrm{kg}$ of product. Emissions intensity (total GHG emissions per kg of product; Table 5) were not significantly different between environments, at 14.85 and $15.51 \mathrm{~kg} / \mathrm{kg}$ product, respectively. Nitrogen and $\mathrm{P}$ losses were low in both environments, and lowest in the low rainfall scenarios $(\mathrm{P}<0.01$; Table 5).

\section{Comparing BCS change and winter crop choice}

Changes in BCS interacted with winter crop choice when testing whole farm eco-efficiency (Table 6). The productivity of both the farm system and the sheep flock were lowest when fodder beet was fed and BCS change was -0.5 during late pregnancy. Sheep flock productivity was intermediate when BCS change was -0.5 and brassica-based crops were fed. However, if BCS loss was eliminated through improved feeding, there was no difference in production associated with winter crop choice.

These differences were reflected in all aspects of GHG emissions per hectare, being lowest for the lowest productivity treatment of fodder beet cropping with a $-0.5 \mathrm{BCS}$ change. Some changes in $\mathrm{N}$ fertiliser use were noted, though these resulted in very minor changes in GHG emissions, with the contribution being only $0.5 \%$ on the farm using the greatest amounts of fertiliser (data not presented). However, the reverse occurred when testing GHG emission intensity (per $\mathrm{kg}$ of product), with the maintenance of BCS providing the lowest GHG emissions per $\mathrm{kg}$ of product at $15.8 \mathrm{~kg} \mathrm{CO}$ equivalents $/ \mathrm{kg}$ product. However, a BCS change of -0.5 when feeding fodder beet resulted in an emissions rate of $18.9 \mathrm{~kg} \mathrm{CO} 2$ equivalents $/ \mathrm{kg}$ product.

Estimated $\mathrm{N}$ losses were relatively low, being approximately $10 \mathrm{~kg} / \mathrm{ha}$ when fodder beet was used and $12 \mathrm{~kg} / \mathrm{ha}$ when conventional brassica crops were used (Table 6). Phosphorus losses were extremely low, averaging $0.5 \mathrm{~kg} / \mathrm{ha}$, with no significant variations estimated between treatments (data not shown).

\section{Discussion}

Varying impacts of BCS change on reproductive performance have been reported by many authors and these impacts interact strongly with the nutrition available at the time (reviewed by Kenyon et al., 2014). However, practical investigations of the impacts of BCS on commercial farms have generally demonstrated benefits in ewe flock productivity (Morgan-Davies et al., 2008; Stevens et al., 2011; Casey et al., 2013; EverettHincks et al., 2013; Mathias-Davis et al., 2013; Johns et al., 2016; McCoard et al., 2020). This study used results from farm practice to quantify the potential impacts of changes in BCS and winter feeding practices on GHG emissions and $\mathrm{N}$ and $\mathrm{P}$ loss, as well as production of meat and fibre. The additional impact of feeding fodder beet (Hammond et al., 2021) on ewe BCS loss and subsequent lamb loss, and reduced liveweight gain from birth to weaning, caused a significant reduction in whole flock productivity, even when mitigating

Table 6 Interactions between ewe body condition score (BCS) change in mid-late pregnancy and winter fodder crops on the ecoefficiency of sheep flocks, expressed as production (meat and fibre), methane, nitrous oxide and total greenhouse gas per hectare and per $\mathrm{kg}$ of product, and nitrogen losses per hectare.

\begin{tabular}{|c|c|c|c|c|c|c|}
\hline & \multirow{2}{*}{$\begin{array}{l}\text { Winter crop } \\
\text { Change in mid-late pregnancy }\end{array}$} & \multicolumn{2}{|c|}{ Brassica } & \multicolumn{3}{|c|}{ Fodder Beet } \\
\hline & & 0 & -0.5 & 0 & -0.5 & LSD \\
\hline \multirow[t]{2}{*}{ Production (kg product/ha/yr) } & Total & $190^{a}$ & $173^{b}$ & $194^{a}$ & $160^{c}$ & 9 \\
\hline & Sheep & $152^{a}$ & $135^{b}$ & $156^{a}$ & $122^{c}$ & 9 \\
\hline \multirow[t]{3}{*}{ Total (kg CO$\left.{ }_{2} \mathrm{E} / \mathrm{ha} / \mathrm{yr}\right)$} & Methane & $1918^{b}$ & $1874^{c}$ & $1983^{a}$ & $1871^{c}$ & 39 \\
\hline & Nitrous oxide & $438^{b}$ & $425^{c}$ & $454^{a}$ & $425^{c}$ & 9 \\
\hline & Total GHG & $2356^{b}$ & $2299^{c}$ & $2437^{a}$ & $2295^{c}$ & 48 \\
\hline \multirow[t]{3}{*}{ Intensity (kg CO${ }_{2} \mathrm{E} / \mathrm{kg}$ product) } & Methane & $12.9^{c}$ & $14.1^{b}$ & $12.9^{c}$ & $15.4^{a}$ & 0.3 \\
\hline & Nitrous oxide & $2.9^{c}$ & $3.2^{b}$ & $2.9^{c}$ & $3.5^{a}$ & 0.1 \\
\hline & Total GHG & $15.8^{c}$ & $17.3^{b}$ & $15.8^{c}$ & $18.9^{a}$ & 0.4 \\
\hline Nitrogen loss & (kg/ha/yr) & $12.4^{\mathrm{a}}$ & $12.3^{a}$ & $10.6^{\mathrm{b}}$ & $10.0^{b}$ & 1.4 \\
\hline
\end{tabular}

Means with different superscripts within rows are significantly different $(P<0.05)$; LSD=Least Squares Difference of the mean $(P<0.05)$ 
measures, such as altering lamb finishing profiles or utilising supplements, were implemented.

A key to ensuring that BCS could be maintained was the addition of a high protein supplement to balance the low protein fodder beet diet (Knol et al., 2019). When BCS loss was mitigated by balancing protein requirements, the whole flock productivity was restored, as was the eco-efficiency of the flock and the farm. Fodder beet is only one example of a low protein diet that may be fed during late pregnancy. Others include high yielding swedes and low protein silages. Hence, this example may apply to a wider range of current industry feeding practices.

Understanding how ecoefficiency metrics, such as GHG emissions, farm productivity and $\mathrm{N}$ leaching losses, change as a consequence of a new technology or management practice is becoming increasingly important. The analysis of potential impacts of using fodder beet as a mid-to-late pregnancy feed for breeding ewes demonstrated a significant interaction with change in BCS. Increases in lambing percentage and lamb growth rates in the last 20 years have been major contributor to improvements in the ecoefficiency of sheep farms in New Zealand, mainly on hill country (MacKay et al., 2012). Alterations in productivity, driven by lamb survival and growth rates from birth to weaning, demonstrated that these variations remain important in driving on-farm ecoefficiency. Previously reported studies (MacKay et al., 2012, Dodd et al., 2020) have demonstrated this relationship between sheep flock performance and whole farm ecoefficiency. Changes in livestock performance reduced GHG emissions intensity from 25 to $15 \mathrm{~kg}$ from 1990 to 2002 (Dodd et al., 2020), which was similar to results reported by Dynes et al. (2011) of $14.1-17.8$ in a range of farm management scenarios on North Island hill country. MacKay et al. (2012) noted a decrease in GHG emissions intensity from approximately 25 to $15 \mathrm{~kg}$ between 1990 and 2010 on hard hill country, although they reported no net change on easy hill country with an average GHG emissions intensity of approximately 15 $\mathrm{kg} / \mathrm{yr}$ throughout in the same time-period. Greenhouse gas emissions in the current trial were lower than those reported by MacKay et al. (2012), most likely driven by lower rainfall $(1500 \mathrm{~mm}$ and $1250 \mathrm{~mm} v s .1090 \mathrm{~mm}$ and $590 \mathrm{~mm}$ ). The current work provides an insight into the on-farm changes that may be achieved within similar environments and management when choosing winter forage options, and the interactions that may occur if nutritional targets vary.

Total annual GHG emissions of $2998 \mathrm{~kg} \mathrm{CO}_{2}$-e/ha and $2259 \mathrm{~kg} \mathrm{CO}$-e/ha for the high and low rainfall farms respectively (Table 5) were comparable to the findings of Hutchinson et al. (2019), who analysed 60 New Zealand sheep and beef farms and found $50 \%$ of the farms produced between 2,891 and 4,597 $\mathrm{kg} \mathrm{CO}_{2}$-e/ha.

The lack of significant differences in GHG emissions per $\mathrm{kg}$ of product between the low and high rainfall farms was likely due to the low rainfall farms having a higher product/ha from the beef enterprise. These farms represent Class 2 and Class 6 farm types in the Beef + Lamb NZ Economic Survey data set (Beef + Lamb NZ 2021a,b). As such, the greater amount of steep land (Table 1) resulting in more variable production conditions and often lower feed quality available, which was then managed through greater numbers of cattle, especially breeding cows. It was interesting to note relatively similar GHG intensity values from both of these types of property, regardless of rainfall. This result reinforced the results reported by MacKay et al. (2012), which demonstrated greater overall gains in productivity in more marginal environments (low rainfall) relative to higher producing environments (high rainfall) in recent times.

There is limited data available on the effect of brassicas on nitrous oxide $\left(\mathrm{N}_{2} \mathrm{O}\right)$ emissions from grazing systems (Thomson et al., 2016). The data available regarding fodder beet on enteric methane suggested that it has a greater reducing effect than feeding brassicas (Thomson et al., 2016). Estimated reductions in GHG of $20-35 \%$ per $\mathrm{kg}$ DM eaten may be possible with both brassica and fodder beet diets (Thompson et al., 2016), which suggested that including brassicas in the calculations would further reduce enteric emissions by between 5 and $10 \%$ in such environments, if feed-based methane emission factors were considered.

Recent research has shown that lactating cows produce the least amount of methane on a fodder beet diet compared with a pasture diet, and low protein fodder beet can reduce urinary $\mathrm{N}$ excretion and, consequently, nitrate leaching and nitrous oxide $\left(\mathrm{N}_{2} \mathrm{O}\right)$ emissions (Jonker et al., 2017). However, these benefits have not yet been captured in the GHG inventory. For inclusion in the NZ inventory, other variables that can influence GHG emissions, such as soil cultivation, grazing management and environmental processes of nitrate leaching, nitrification, $\mathrm{N}_{2} \mathrm{O}$ emissions and soil carbon accumulation, need to be considered (Thompson et al., 2016). Further research and the application to sheep and beef farms is needed to realise the potential gains to be made in using fodder beet and brassica on the ecoefficiency of production.

Estimated nutrient losses were significantly higher under the control scenarios when compared to the fodder beet scenarios, which was most likely influenced by the smaller area of fodder beet grown compared to the swede and kale crops. Therefore, the development of a significant 'hot spot' for nutrient losses due to the high yield potential of fodder beet appears to have been offset by the reduction in total area required. 


\section{Conclusions}

The role of ewe BCS in the reproductive success of sheep was highlighted in eco-efficiency calculations at a whole farm level, and was repeated in both high and low rainfall environments. Specific winter crops can change this relationship, due to the the impact of low protein fodder beet feeding in multiple-bearing ewes in mid-to-late pregnancy on lamb survival and growth to weaning, which, when represented at farm scale, further reduced eco-efficiency. However, mitigating such impacts using a balanced supplement was able to restore whole farm productivity and ecoefficiency. The use of winter crops for feeding pregnant ewes should be monitored carefully and the addition of a protein supplement to balance the diet is a worthy inclusion to maintain eco-efficiency.

\section{ACKNOWLEDGEMENTS}

The authors would like to thank the team at Beef + Lamb NZ for their provision of anonymous farm data for analysis and AgResearch Strategic Science Investment Fund for funding of the work.

\section{REFERENCES}

Beef + Lamb NZ. 2021a. Economic Service Sheep and BeefFarm Survey, Otago/Southland 2021/22 Forecast and Quintile analysis (P21018). https://beeflambnz. $\mathrm{com} / \mathrm{sites} /$ default/files/data/files/2020\%20SSI.pdf Accessed 27 September 2021.

Beef + Lamb NZ. 2021b. Economic Service Sheep and Beef Farm Survey, Marlborough/Canterbury 2021/22 Forecast and Quintile analysis (P21018). https://beeflambnz.com/sites/default/files/data/ files/2020\%20CSI.pdf Accessed 27 September 2021.

Casey MJ, Scandrett JS, Stevens DR. 2013. Ewe body condition: Does farmer practice meet research guidelines. Proceedings of the $22^{\text {nd }}$ International Grassland Congress. Saskatoon, Canada, pp 18821883. https://www.grassland.org.nz/publications/ nzgrassland_publication_2571.pdf

Chakwizira E, Fletcher AL, Meenken E, Johnstone P, Maley S, Arnold N, Armstrong S, George M, Sim RE, Minchin R, Morton JD, Stafford AD. 2011. Dry matter response of swede crops to phosphorus $(\mathrm{P})$ and nitrogen $(\mathrm{N})$ application in Southland and central North Island regions of New Zealand. Proceedings of the Agronomy Society of New Zealand 41: 23-37. https://www.agronomysociety.org.nz/files/2011 3 . DM response of swede.pdf

Chakwizira E, Meenken ED, Maley S, George M, Hubber R, Morton I, Stafford A. 2013. Effects of potassium, sodium and chloride fertiliser rates on fodder beet yield and quality in Canterbury. Proceedings of the New Zealand Grassland Association 75: 261-270 https://doi.org/10.33584/jnzg.2013.75.2905
Chakwizira E, de Ruiter JM, Maley S, Dellow SJ, George MJ, Michel AJ. 2014. Water use efficiency of fodder beet crops. Proceedings of the New Zealand Grassland Association 76: 125-134. https://doi. org/10.33584/jnzg.2014.76.2969

Corner-Thomas RA, Hickson RE, Morris ST, Back PJ, Ridler AL, Stafford KJ, Kenyon PR. 2015. Effects of body condition score and nutrition in lactation on twinbearing ewe and lamb performance to weaning. New Zealand Journal of Agricultural Research 58: 156-169. https://doi.org/10.1080/00288233.2014.987401

De Ruiter J, Wilson D, Maley S, Fletcher A, Fraser T, Scott W, Berryman S, Dumbleton A, Nicol W. 2009. Management practices for forage brassicas. https://pdfs.semanticscholar.org/ f854/981d50c06975ed9b93b6566ceebadb890285. pdf. Accessed 15 March 2020.

Dodd, MB, Rennie G, Kirschbaum, MUF, Giltrap DL, Smiley D, van der Weerden TJ. 2020. Improving the economic and environmental performance of a New Zealand hill country farm catchment: 4 . Greenhouse gas and carbon stock implications of land management change, New Zealand Journal of Agricultural Research, https://doi.org/10.1080/0028 8233.2020.1775656

Dumbleton A, Gowers S, Conner A, Christie M, Kenny P, Mulcock H, Charteris B. 2012. Cleancrop Brassica Systems: The development of herbicide resistant brassica crops for New Zealand farming systems. Proceedings of the New Zealand Grassland Association 74: 25-30. https://doi.org/10.33584/ jnzg.2012.74.2880

Dynes RA, Smeaton DC, Rhodes AP, Fraser TJ, Brown MA. 2011. Modelling farm management scenarios that illustrate opportunities farmers have to reduce greenhouse gas emissions while maintaining profitability. Proceedings of the New Zealand Society of Animal Production 71: 149-178.

Everett-Hincks JM, Blair HT, Stafford KJ, LopezVillalobos J. 2004. The effect of ewe nutrition on maternal behaviour score and litter survival. Proceedings of the New Zealand Society of Animal Production 64: 188-191. http://www.nzsap.org/ proceedings/2004/effect-ewe-nutrition-maternalbehaviour-score-and-litter-survival

Everett-Hincks JM, Stevens DR, Rendel JM, Smith TR, Smith PJ. 2013. The effect of ewe prelamb body condition on triplet lamb performance in a commercial flock. Proceedings of the New Zealand Society of Animal Production 73: 126-130. http://www.nzsap. org/proceedings/2013/effect-ewe-prelamb-bodycondition-triplet-lamb-performance-commercial-flock Fennessey PF, Glennie SF, McCorkindale AB. 2016. Innovations behind the farm gate that will influence performance of hill farming. In: Thom, ER. Ed. 
Hill Country Symposium. Grassland Research and Practice Series 16. Dunedin, New Zealand: New Zealand Grassland Association, pp. 15-20. https:// doi.org/10.33584/rps.16.2016.3253

Flay KJ, Ridler AL, Compton CWR, Kenyon PR. 2021. Ewe wastage in New Zealand commercial flocks: extent, timing, association with hogget reproductive outcomes and BCS. Animals 11: 779. https://doi. org/10.3390/ani11030779

Genstat 2017. GenStat for Windows 18th Edition. VSN International Ltd, Oxford.

Gibbs J. 2014. Fodder beet in the New Zealand Dairy industry. https://side.org.nz/wp-content/ uploads/2014/05/4.3-Fodder-Beet-GIBBS.pdf. Accessed 15 April 2021.

Gowers S, Butler R, Armstrong SD. 2006. Yield comparisons of old and new cultivars of swedes (Brassica napus ssp. napobrassica) in Southland, New Zealand. New Zealand Journal of Crop and Horticultural Science 34: 109-114. https://doi.org/1 0.1080/01140671.2006.9514394

Hammond KJ, Sandoval E, McKenzie CM, Lees S, Pacheco D, McCoard SA. 2021. The effect of a fodder beet versus rye-grass grazing regime during mid-to-late gestation twin-bearing ewes on dam and progeny performance and lamb survival. New Zealand Journal of Agricultural Research. https:// doi.org/10.1080/00288233.2021.1879175

Hutchinson KJ, Rennie GM, Vibart RE, Mercer GJK, O'Neill K, Burtt AN, Chrystal JM, Devantier B, Smiley DR, Taylor AL, Thompson BR, Wall AJ, Dynes RA. 2019. BRIEF COMMUNICATION: Greenhouse gas emissions from New Zealand sheepand beef- farm systems. New Zealand Journal of Animal Science and Production 79: 56-60. http:// www.nzsap.org/proceedings/brief-communicationgreenhouse-gas-emissions-new-zealand-sheep-andbeef-farm-systems

Jefferies B. 1961. Body condition scoring and its use in management. Tasmanian Journal of Agriculture 32: 19-21.

Johns C, Johns J, Stevens DR. 2016. Increasing lamb survival and lamb weaning weight through feeding high fecundity crossbred sheep. In: Thom, ER. Ed. Hill Country Symposium. Grassland Research and Practice Series 16. Dunedin, New Zealand: New Zealand Grassland Association, pp.323-328. https:// doi.org/10.33584/rps.16.2016.3244

Jonker A, Scobie D, Dynes R, Edwards GR, De Klein CAM, Hague H, McAuliffe R, Taylor AL, Knight T, Waghorn G. 2017. Feeding diets with fodder beet decreased methane emissions from dry and lactating dairy cows in grazing systems. Animal Production Science 57 (7) 1445-1450. https://doi.org/10.1071/ AN16441
Judson HG, McKenzie S, Robinson S, Nicholls A, Moorhead AJE. 2016. Measurement techniques and yield estimates of fodder beet in Canterbury and Southland. Journal of New Zealand Grasslands 78: 177-180. https://doi.org/10.33584/jnzg.2016.78.502

Kenyon PR, Maloney SK, Blache D. 2014. Review of sheep body condition score in relation to production characteristics. New Zealand Journal of Agricultural Research 57: 38-64. https://doi.org/10.1080/002882 33.2013 .857698

Kenyon PR, Morris ST, Stafford KJ, West DM. 2011. Effect of ewe body condition and nutrition in late pregnancy on the performance of triplet-bearing ewes and their progeny. Animal Production Science 51: 557-564. https://doi.org/10.1071/AN10192

Knol FW, Erichsen C, Jonker A, Sandoval E, Pachecho D, Hea SY, McCoard SA. 2019. Effect of a fodder beet or lucerne-chaff-based diet on triplet-bearing ewe live weight, body condition score and lamb birth weight. New Zealand Journal of Animal Science and Production 79: 168-170. http://www. nzsap.org/proceedings/brief-communication-effectfodder-beet-or-lucerne-chaff-based-diet-tripletbearing-ewe

KPMG. 2014. SFF says tastier beef on the way.

MacKay AD, Rhodes AP, Power I, Wedderburn ME. 2012. Has the ecoefficiency of sheep and beef farms changed in the last 20 years? Proceedings of the New Zealand Grassland Association 74: 11-16. https:// doi.org/10.33584/jnzg.2012.74.2878

Marshall PR, McCall DG, Johns KL. 1991. Stockpol: a decision support model for livestock farms. Proceedings of the New Zealand Grassland Association 53: 137-140. https://doi.org/10.33584/ jnzg.1991.53.2013

Mathias-Davis HC, Shackell GH, Greer GJ, Bryant AI, Everett-Hincks JM 2013. Ewe body condition score and the effect on lamb growth rate. Proceedings of the New Zealand Society of Animal Production 73: 131-135. http://www.nzsap.org/proceedings/2013/ ewe-body-condition-score-and-effect-lamb-growthrate

McCoard S, Hea S-Y, McKenzie C, Hammond K, Smith T. 2020. Impact of change in body condition score in mid-late pregnancy in ewes fed a mixed diet on lamb survival and performance. Journal of New Zealand Grasslands 82: 211-219. https://doi.org/10.33584/ jnzg.2020.82.442

Milne GD, Direen C, Kitson E, Evans P, Cleland RG, Treder D. 2014. Performance of fodder beet cultivars in the South Island. Proceedings of the New Zealand Grassland Association 76: 141-144. https://doi. org/10.33584/jnzg.2014.76.2955

Ministry for Primary Industries 2021. Methodology for calculation of New Zealand's agricultural greenhouse 
gas emissions. Version 7. 117-179. https://www.mpi. govt.nz/dmsdocument/13906/direct Accessed 27 September 2021.

Morgan-Davies C, Waterhouse A, Pollock ML, Milner JM. 2008. Body condition score as an indicator of ewe survival under extensive conditions. Animal Welfare 17: 71-77.

Pacheco D, Waghorn G, Dalley D. 2016. Plasma amino acid profiles of lactating dairy cows fed fodder beet and ryegrass diets. Proceedings of the New Zealand Society of Animal Production 76: 62-64. http:// www.nzsap.org/proceedings/brief-communicationplasma-amino-acid-profiles-lactating-dairy-cowsfed-fodder-beet-and

Prendergast SL, Gibbs SJ. 2015. A comparison of microbial protein synthesis in beef steers fed ad libitum winter ryegrass or fodder beet. Proceedings of the New Zealand Society of Animal Production 75: 251-256. http://www.nzsap.org/proceedings/2015/ comparison-microbial-protein-synthesis-beef-steersfed-ad-libitum-winter-ryegrass
Shepherd M, Wheeler D. 2012. OVERSEER $®$ Nutrient Budgets - the next generation. In: Advanced Nutrient Management: Gains from the Past - Goals for the Future. (Eds L.D. Currie and C L. Christensen). Occasional Report No. 25. Fertilizer and Lime Research Centre, Massey University, Palmerston North, New Zealand. 9 pages. http://flrc.massey. ac.nz/publications.html.

Stevens DR, Casey MJ, Scandrett JS, Baxter GS. 2011. Winter feeding - changing labour requirements and productivity. Proceedings of the New Zealand Grassland Association 73: 51-56. https://doi. org/10.33584/jnzg.2011.73.2850

Stevens DR, Canton M, Harpham S. 2021. Farming with reduced winter cropping: the risks and practicalities. Journal of New Zealand Grasslands this volume.

Thomson BC, Hammond KJ, Muir PD. 2016. New Zealand Agricultural Greenhouse Gas Research Centre. A Review of Greenhouse Gas Emissions from the Use of Brassica and Fodder Beet Forages on New Zealand Farms. Retrieved 18 May 2021 from: https://www.nzagrc.org.nz/science-publication 